\title{
Keberadaan Krustasea di Kawasan Vegetasi Mangrove Tugurejo, Semarang
}

\author{
Retno Hartati \\ Program Studi Ilmu Kelautan, Fakultas Perikanan dan Ilmu Kelautan,Universitas Diponegoro \\ Kampus Tembalang, Semarang 50275 Telp/Fax. 024-7474698 \\ email: retnohartati.undip@yahoo.com
}

\begin{abstract}
Abstrak
Hutan mangrove merupakan ekosistem yang unik karena terjadi akibat perpaduan antara habitat darat dan laut. Ekosistem mangrove juga merupakan tempat hidup berbagai jenis hewan benthos termasuk krustasea yang memegang peranan penting dalam ekosistem tersebut. Adanya perubahan fungsi lahan untuk berbagai kepentingan manusia diduga akan berpengaruh terhadap kondisi kelimpahan krustaseayang terdapat di kawasan tersebut. Penelitian ini bertujuan untuk menganalisais komposisi dan struktur komunitas makrozoobenthos krustasea di kawasan mangrove Tugurejo, Semarang. Pengambilan sampel dilakukan dengan 2 metode yaitu kualitatif dan kuantitatif. Hasil penelitian menunjukkan terdapat 22 jenis makrozoobenthos krustasea, dari Infra Ordo Brachyura ditemukan 14 jenis yang termasuk ke dalam 5 famili, Infra Ordo Macrura ditemukan 4 jenis yang termasuk ke dalam 4 famili, dari Isopoda ditemukan 3 jenis dan dari Copepoda ditemukan satu jenis biota. Nilai indeks keanekaragaman semua stasiun termasuk kategori sedang. Indeks keseragaman rendah sampai tinggi. Terdapat dominansi species di Stasiun B (vegetasi pohon) dan C (vegetasi sapling). Pola sebaran krustasea mengelompok. Nilai indeks kesamaan komunitas termasuk kategori rendah dan tinggi. Secara umum jumlah krustasea pada infra ordo Brachyura jantan lebih banyak dari betina, dan jumlah infra ordo Brachyura betina yang bertelur 23,07\% dari jumlah betina yang ditemukan.
\end{abstract}

Kata Kunci : Mangrove, Krustasea, Komposisi dan Kelimpahan

\begin{abstract}
Mangrove forest is unique ekosisyem, as occurs due to a combination of terrestrial and marine habitats. Mangrove ecosystem is also home to various species of animals living benthos include crustaceans which play an important role in the ecosystem. The existence of a land use change for a variety of human interests is expected to affect the abundance krustaseayang conditions contained in the region. The study was conducted in September 2011 - March 2012. The purpose of this study to determine the composition and abundance of crustaceans in the mangrove areas makrozoobenthos village Tugurejo, district Tugu, the city of Semarang. This study is descriptive. Sampling was done by two methods, namely qualitative and quantitative. The results show found at least 22 species, of the Order Infra brachyura found 14 species belonging to the five families, Infra Order Macrura found four species belonging to the four families, are found three species of Isopoda and found one species of copepod biota. Diversity index value of all the stations including the category of being. For uniformity index of $A$ and $D$ category stations is high, $B$ and $C$ category stations is low. To the dominance of the stations $A$ and $D$ did not show any dominance among species, stations $B$ and $C$ indicate the presence of domidansi. Clumped distribution patterns crustaceans. Community similarity index values including low and high categories. In general, the number of crustaceans in the infra order Brachyura more males than females, and a number of infra order Brachyura laying females $23.07 \%$ of the females were found.
\end{abstract}

Key words: Mangrove, Crustaceans, Composition and Abundance

\section{PENDAHULUAN}

Semarang memiliki kawasan vegetasi mangrove yang cukup besar yaitu di sepanjang pantura, salah satunya di daerah Kelurahan Tugurejo, Kecamatan Tugu, Kota Semarang.
Mangrove mempunyai beberapa fungsi baik secara fisik, ekologi, maupun ekonomi. Menurut Saenger (2002) fungsi secara fisik mangrove mampu berperan sebagai penahan abrasi, gelombang, angin kencang bagi wilayah daratan,
*) Corresponding author

buloma.undip@gmail.com http://ejournal.undip.ac.id/index.php/buloma

Diterima/Received : 27-07-2016

Disetujui/Accepted : 20-08-2016 
pengendali intrusi air laut, dan pembangun lahan melalui proses sedimentasi. Fungsi secara ekologis mangrove berperan sebagai penyedia nutrien, tempat pemijahan, pembesaran, dan mencari makan (Snedaker, 1984; Nontji, 1987) dan secara ekonomis mangrove dapat dimanfaatkan sebagai kayu bakar, bahan kertas, bahan konstruksi.

Vegetasi mangrove sangat penting bagi berbagai jenis biota yang hidup di kawasan mangrove maupun di perairan sekitarnya, salah satu hewan makrobenthos yang berasosiasi dengan mangrove adalah krustasea. Secara ekologis, daerah mangrove memiliki produktifitas yang tinggi karena kaya akan nutrien serta memiliki temperatur, cahaya, $\mathrm{pH}$, oksigen, dan salinitas yang optimum serta kondisi perairan yang tenang sehingga menjadikannya sebagai habitat yang cocok untuk krustasea (Hogart, 1999).

Pemilihan lokasi penelitian ini berdasarkan tipe vegetasi mangrove, sedimen, dan kerapatan mangrove yang berbeda sehingga dapat diketahui komposisi dan kelimpahan krustasea pada lokasi dengan kondisi lingkungan yang berbeda. Pemilihan vegetasi mangrove sendiri untuk Stasiun A dan B merupakan mangrove pohon (dewasa) dengan substrat yang berbeda, Stasiun C dan D merupakan sapling dan seedling mangrove dengan subtrat yang sama.

Karena adanya perbedaan tipe dan kerapatan vegetasi mangrove serta jenis sedimen, maka penelitian dibagi menjadi empat stasiun yang tiap stasiunnya terdiri dari tiga titik. Stasiun A berada di tepi sungai Tapak dengan vegetasi mangrove yang mendominasi adalah Avicennia marina yang tingginya sekitar 2-3,5 m, kerapatan rata-rata pohon 1042 ind./ha dengan substrat dasar berupa lanau pasiran. Stasiun B berada pada muara sungai yang berjarak kurang lebih $500 \mathrm{~m}$ dari laut dan vegetasi mangrove yang mendominasi adalah Avicennia marina ketinggian sekitar 3 - $4 \mathrm{~m}$ dengan kerapatan rata-rata pohonnya 2089 ind./ha dan bersubstrat lanau pasiran. Stasiun C berada dekat tambak dan vegetasi yang mendominasi adalah Avicennia marina dengan kerapatan rata-rata pohon 814 ind./ha dan tinggi sekitar 2,5-4 m dengan substrat berupa pasir. Stasiun D berada di pesisir Pantai Maron dengan vegetasi mangrove yang mendominasi stasiun ini adalah sapling dan secdling Rhizophora mucronata dengan tinggi 0,5 - $1 \mathrm{~m}$ dan bersubstrat dasar berupa pasir. Penelitian ini bertujuan untuk menganalisais komposisi dan struktur komunitas makrozoobenthos krustasea di kawasan mangrove Tugurejo, Semarang.

\section{MATERI DAN METODE}

Materi penelitian ini adalah krustasea yang diambil dari kawasan vegetasi mangrove Tugurejo, Semarang. Parameter lingkungan yang diukur sebagai data pendukung meliputi salinitas, $\mathrm{pH}$, suhu (diukur dari pore water atau air pori), dan pasang surut. Metode yang digunakan dalam penelitian ini adalah metode deskriptif-eksploratif (Suryabrata, 1992).

Pengambilan sampel dilakukan dengan dua metode, yaitu dengan metode kualitatif dan kuantitatif. Kualitatif, sampling dilakukan dengan cara mengambil biota dengan tangan (hand picking) yang berada didalam plot sampel yang berukuran $5 \times 5 \mathrm{~m}^{2}$ menggunakan tangan (hand picking). Secara kuantitatif, dengan cara mengambil sampel substrat dari plot sampel yang berukuran $1 \times 1 \mathrm{~m}^{2}$ dengan kedalaman $10 \mathrm{~cm}$ yang diambil dari dalam plot sampel $5 \times 5 \mathrm{~m}^{2}$ (Sasekumar, 1974). Sampel imasukkan ke dalam botol contoh atau kantong plastik dan diawetkan dengan alkohol $70 \%$. Semua biota yang dikoleksi dibawa ke laboratorium diidentifikasi dengan Holthuis (1955), Hall (1962), Sakai (1976a,b), Burukovskii (1982), Brower et al. (1990), Carpenter and Niem (1998), Ng Peter et al. (2008) dan Rahayu dan Setyadi (2009) serta dihitung jumlah individunya. Kepadatan krustasea dihitung berdasarkan banyaknya individu per luas daerah pengambilan contoh (Brower dan Zar, 1977) dan selanjutnya dianalisa dengan cara mengitung Indeks Keanekaragaman, Indeks Keseragaman dan Indeks Dominansi menggunakan rumus Shannon-Wiener (Krebs, 1989).

\section{HASIL DAN PEMBAHASAN \\ Komposisi Krustasea}

Jenis-jenis krustasea yang ditemukan di lokasi penelitian adalah infra ordo Brachyura yang terdiri dari 14 spesies yang termasuk ke dalam lima famili yang berbeda, yaitu Helice sp. dan Metopograpsus latifrons (Grapsidae); Sesarma (Parasesarma) charis, Sesarma (Episesarma) lafondi, Sesarma (Parasesarma) plicatum, Metaplax elegan, Metaplax sp. (Sesarmidae); Uca (Deltuca) dussumieri dussumieri, Uca (Deltuca) [coarctata] forcipata, Uca (Australuca) bellator minima, Uca (Deltuca) [coarctata] arcuata, Uca sp, Uca sp.1 (Ocypodidae); Paracleistostoma sp (Camptandriidae); Pilumnus hirtellus (Xanthidae). Infra ordo Macrura di daerah penelitian terdiri 
dari tiga spesies yang termasuk ke dalam tiga famili, yaitu Acetes sp. (Sergestidae); Cerapus sp. (Ischyroceridae); dan Gammaropsis sp. (Isaeidae). Dan tiga spesies yang termasuk isopoda diantaranya adalah Aega sp., Desmosomatid sp., Ligia sp. Hasil ini lebih sedikit dibandingan dengan penelitian Hartati et al. (2008) di vegetasi mangrove Ujung pangkah Gresik yang menemukan 18 spesies krustasea dari 9 famili, yaitu Alpheus sp 1, Alpheus sp 2 (Alpheidae), Paracleistostoma (Camtandridae), Coenobitidae sp (Coenobitidae), Ozius sp (Eriphiidae), Metaplax $\mathrm{sp}, \quad$ Perisesarma $\mathrm{sp}, \quad$ Metopograpsus $\mathrm{sp}$ (Grapsidae), Lysioquillina sp (Lysioquillidae), llyoplax sp, Uca sp 1, Uca sp 2, Macrophthalmus sp (Ocypodidae), Clibanarus sp (Paguridae), Scylla sp 1, Scylla sp 2, Thalamita sp, dan Portunus sp (Portunidae).

\section{Kelimpahan krustasea}

Secara umum rata-rata kelimpahan krustasea di setiap stasiun bervariasi, dan Stasiun B (tepi sungai) memiliki nilai kelimpahan paling tinggi dari stasiun lainnya $1136 \mathrm{ind} / 25 \mathrm{~m}^{2}$,

Tabel 1. Komposisi jenis krustasea di kawasan vegetasi mangrove Tugurejo, Semarang

\begin{tabular}{|c|c|c|c|c|c|c|c|c|c|c|c|c|}
\hline \multirow{2}{*}{ Jenis } & \multicolumn{3}{|c|}{ Stasiun A } & \multicolumn{3}{|c|}{ Stasiun B } & \multicolumn{3}{|c|}{ Stasiun C } & \multicolumn{3}{|c|}{ Stasiun D } \\
\hline & 1 & 2 & 3 & 1 & 2 & 3 & 1 & 2 & 3 & 1 & 2 & 3 \\
\hline \multicolumn{13}{|l|}{ Brachyura } \\
\hline \multicolumn{13}{|l|}{ Grapsidae } \\
\hline Helice sp. & - & + & + & + & + & + & - & - & - & - & - & - \\
\hline Metopograpsus latifrons & + & - & - & + & - & - & + & - & - & - & - & - \\
\hline \multicolumn{13}{|l|}{ Sesarmidae } \\
\hline Sesarma (Parasesarma) charis & - & - & - & - & - & - & - & - & - & - & + & - \\
\hline Sesarma (Episesarma) lafondi & - & + & - & - & - & - & - & - & - & - & - & - \\
\hline Sesarma (Parasesarma) plicatum & - & + & + & - & - & + & - & - & + & - & - & - \\
\hline Metaplax elegans & - & + & + & + & + & + & - & + & + & - & - & - \\
\hline \multicolumn{13}{|l|}{ Ocypodidae } \\
\hline Uca (Deltuca) dussumieri dussumieri & - & - & - & - & - & - & - & - & + & - & - & - \\
\hline Uca (Deltuca)[coarctata] forcipata & - & - & + & - & - & - & - & - & - & - & - & - \\
\hline Uca (Australuca) bellator minima & - & + & - & + & - & + & - & - & + & - & - & - \\
\hline Uca (Deltuca) [coarctata] arcuata & - & - & + & - & - & - & - & - & + & - & - & - \\
\hline Uca sp. & - & + & + & + & - & + & - & - & + & - & - & - \\
\hline$U c a$ sp.1 & - & - & + & - & - & - & - & - & - & - & - & - \\
\hline \multicolumn{13}{|l|}{ Camptandriidae } \\
\hline Paracleistostoma sp. & - & - & - & - & - & - & - & - & - & - & + & + \\
\hline \multicolumn{13}{|l|}{ Xanthidae } \\
\hline Pilumnus hirtellus & - & - & + & - & - & - & - & - & - & - & - & - \\
\hline
\end{tabular}

Sergestidae

Acetes sp.

Ischyroceridae

Cerapus sp.

Isaeidae

Gammaropsis sp.

Atyidae

Atyopsis spinipes

\section{Macrura}

\begin{tabular}{lllllllllllll} 
& Isopoda & & & & & & & & & & \\
Aega sp. & -1 & + & - & + & + & + & - & + & - & - & - & - \\
Desmosomatid sp. & - & - & - & - & - & - & - & + & - & - & - & - \\
Ligia sp. & - & + & - & - & + & + & - & + & - & - & - & + \\
\hline
\end{tabular}

\section{Copepoda}

Mesocalanus sp.

\begin{tabular}{lccccccccccc}
\hline Total spesies per substasiun & 1 & 10 & 11 & 6 & 4 & 9 & 2 & 5 & 6 & 1 & 2 \\
\hline Total spesies per stasiun & & 17 & & & 10 & & & 11 & & & 4 \\
\hline
\end{tabular}

Keterangan : + = ditemukan; - = tidak ditemukan 
sedangkan Stasiun D (pesisir pantai) merupakan stasiun yang memiliki nilai kelimpahan paling rendah dibandingkan Stasiun A dan C yaitu 83 ind $/ 25 \mathrm{~m}^{2}$. Kelimpahan krustasea tertinggi terdapat pada Stasiun B disebabkan oleh kondisi mangrove yang lebih baik dibandingkan stasiun lainnya. Kondisi, kerapatan, dan jenis mangrove akan berpengaruh terhadap luas penutupan kanopi dan bahan organik yang dihasilkan. Nilai rata-rata kelimpahan krustasea di kawasan mangrove Ujung Pangkah Gresik berkisar 10-277 ind/m2 (Hartati et al., 2008) yang lebih tinggi dari pada penelitian ini.

Adanya penutupan kanopi yang luas dan rapat akan menyediakan perlindungan bagi krustasea dari sengatan sinar matahari secara langsung, juga dari predator, aksi gelombang, dan produksi bahan organik yang dihasilkan. Tersedianya bahan organik yang tinggi pada Stasiun B $(17,66 \%)$ akan berpengaruh terhadap organisme untuk mencari makan dan tinggal disana termasuk krustasea. Adanya karakteristik tersebut dibawah kanopi dan bahan organik yang tinggi, dimungkinkan akan banyak ditemukan jenis krustasea yang berlindung dibawahnya. Selain itu, substrat pada lokasi ini berupa pasir lanauan yang tersusun dari pair 50,04\%, silt (lanau) 46,6\%, dan clay (lempung) 3,36\% .

\section{Keanekaragaman, Keseragaman dan Dominansi Krustasea di Kawasan mangrove Tugurejo}

Hasil perhitungan Indeks Keanekaragaman $\left(H^{\prime}\right)$ semua stasiun termasuk dalam kategori sedang. Untuk nilai Indeks Keseragaman,Stasiun A dan $D$ termasuk dalam kategori tinggi, sedangkan Stasiun B dan C dalam kategori rendah. Nilai Indeks Dominansi Stasiun A dan Stasiun D tidak ada jenis yang mendominasi (TAD), untuk Stasiun B dan Stasiun C, terdapat jenis yang mendominasi (AD).

Nilai indeks keanekaragaman krustasea di lokasi penelitian yaitu berkisar antara 1,22-2,60 (Tabel 5). Jika berpatokan pada Wilhm (1975) yang mengatakan bahwa jika nilai $\mathrm{H}^{\prime}<1$, maka tingkat keanekaragamannya kecil, jika $1<\mathrm{H}^{\prime}<3$ maka masuk kategori sedang, dan jika H'>3 maka tergolong dalam kategori tinggi. Dan secara umum nilai indeks keanekaragaman krustasea pada lokasi penelitian berada dalam kategori sedang. Dimana keanekaragaman jenis dipengaruhi oleh banyak hal, diantaranya jenis habitat tempat hidup, stabilitas lingkungan, produktifitas, kompetisi, dan penyangga rantai makanan. Nilai keanekaragaman juga menentukan maka tingkat stress atau tekanan yang diterima krustacea oleh lingkungan (Lardicci et al., 1997)

Pertambakan penduduk, rekreasi, aktivitas industri, pembuangan limbah rumah tangga, dan berbagai macam aktivitas lain seperti pelebaran lahan bandara dimungkinkan menjadi salah satu faktor penyebabnya. Semakin baik kondisi lingkungan perairan, maka nilai indeks keanekaragaman jenis biota akan semakin tinggi, begitu juga sebaliknya. Indeks keanekaragaman jenis akan menurun seiring dengan menurunnya kondisi atau kualitas lingkungan perairan.

Clarc (1974) menyatakan bahwa keanekaragaman mengekspresikan variasi spesies yang ada dalam suatu ekosistem, ketika suatu ekosistem memiliki indeks keanekaragaman yang tinggi maka ekosistem tersebut cenderung seimbang. Sebaliknya, jika suatu ekosistem memilki indeks keanekaragaman yang rendah maka mengindikasikan ekosistem tersebut dalam keadaan tertekan atau terdegradasi. Nilai indeks keseragaman krustasea pada penelitian ini berbeda-beda, Stasiun A $(0,63)$, Stasiun B $(0,39)$, Stasiun C $(0,36)$, dan Stasiun D $(0,61)$. Menurut Odum (1993), besarnya indeks keseragaman jenis berkisar antara 0-1. Dimana e> 0,6 berkategori keseragaman jenis tinggi, jika $0,4<\mathrm{e}<0,6$ maka keseragaman jenis berkategori sedang, dan jika $\mathrm{e}<0,4$ maka keseragaman jenis rendah. Jadi untuk Stasiun A dan Stasiun D nilai indeks keseragaman jenis tinggi, dan untuk Stasiun B dan Stasiun C masuk kedalam kategori keseragaman jenis sedang. Dan untuk nilai indeks dominasi pada lokasi penelitian ini hanya Stasiun A dan D yang berkategori tidak ada jenis yang mendominasi (TAD), sedangkan Stasiun B dan C terdapat jenis yang mendominasi (AD), yaitu adanya jenis Cerapus Sp yang ditemukan sangat melimpah (Tabel 2). Hal ini berbeda dengan hasil penelitian Hartati et al. (2008) yang menemukan pesies yang dominan di kawasan mangrove adalah Metaplax sp dari famili Grapsidae.

\section{Pola Sebaran Jenis}

Pola sebaran jenis yang terdapat pada semua stasiun penelitian sebagian besar $65 \%$ mempunyai pola sebaran mengelompok/clumped, $35 \%$ acak/random. Dari 22 jenis krustasea yang ditemukan empat diantaranya Helice sp., Sesarma (Parasesarma) plicatum, Cerapus sp., dan Ligia sp. memiliki pola sebaran jenis mengelompok pada setiap stasiun yang ditemukan. Sedangkan Metopograpsus latifrons, Metaplax elegans, Uca (Australuca) bellator minima, Uca 
Tabel 2. Kelimpahan Total (ind/25 $\mathrm{m}^{2}$ ) krustasea di kawasan vegetasi mangrove Tugurejo, Semarang.

\begin{tabular}{|c|c|c|c|c|}
\hline \multirow{2}{*}{ Jenis } & \multicolumn{4}{|c|}{ Stasiun } \\
\hline & A & B & $\mathrm{C}$ & $\mathrm{D}$ \\
\hline \multicolumn{5}{|l|}{ Brachyura } \\
\hline \multicolumn{5}{|l|}{ Grapsidae } \\
\hline Helice sp & 5 & 4 & & \\
\hline Metopograpsus latifrons & 2 & 1 & 2 & \\
\hline \multicolumn{5}{|l|}{ Sesarmidae } \\
\hline Sesarma (Parasesarma) charis & & & & 1 \\
\hline Sesarma (Episesarma) lafondi & 2 & & & \\
\hline Sesarma (Parasesarma) plicatum & 5 & 4 & 10 & \\
\hline Metaplax elegans & 2 & 7 & 1 & \\
\hline \multicolumn{5}{|l|}{ Ocypodidae } \\
\hline Uca (Deltuca) dussumieri dussumieri & & & 1 & \\
\hline Uca (Deltuca)[coarctata] forcipata & 1 & & & \\
\hline Uca (Australuca) bellator minima & 1 & 2 & 1 & \\
\hline Uca (Deltuca) [coarctata] arcuata & 1 & & 2 & \\
\hline Uca sp & 2 & 2 & 1 & \\
\hline Uca sp.1 & 1 & & & \\
\hline \multicolumn{5}{|l|}{ Camptandriidae } \\
\hline Paracleistostoma $s p$ & & & & 7 \\
\hline \multicolumn{5}{|l|}{ Xanthidae } \\
\hline Pilumnus hirtellus & 1 & & & \\
\hline Macrura & & & & \\
\hline \multicolumn{5}{|l|}{ Sergestidae } \\
\hline Acetes sp & 25 & & & 50 \\
\hline \multicolumn{5}{|l|}{ Ischyroceridae } \\
\hline Cerapus $S p$ & 50 & 275 & 238 & \\
\hline \multicolumn{5}{|l|}{ Isaeidae } \\
\hline Gammaropsis sp & 25 & & & \\
\hline \multicolumn{5}{|l|}{ Atyidae } \\
\hline Atyopsis spinipes & & 25 & & \\
\hline Isopoda & & & & \\
\hline Aega sp & & 617 & & \\
\hline Desmosomatid sp & & & 75 & \\
\hline Ligia $s p$ & 50 & 200 & 75 & 25 \\
\hline Copepoda & & & & \\
\hline Mesocalanus sp & 75 & & & \\
\hline Jumlah & 247 & 1136 & 406 & 83 \\
\hline
\end{tabular}

Tabel 3. Distribusi Nilai dan Kategori Indeks Keanekaragaman (H'), Keseragaman (e) dan Dominansi (C) Krustasea di kawasan vegetasi mangrove Tugurejo, Semarang.

\begin{tabular}{ccccccc}
\hline \multirow{2}{*}{ Stasiun } & \multicolumn{2}{c}{ Keanekaragaman } & \multicolumn{2}{c}{ Keseragaman } & \multicolumn{2}{c}{ Dominansi } \\
\cline { 2 - 7 } & $\mathrm{H}^{\prime}$ & Kategori & $\mathrm{e}$ & Kategori & $\mathrm{C}$ & Kategori \\
\hline $\mathrm{A}$ & 2,60 & Sedang & 0,63 & Tinggi & 0,21 & $\mathrm{TAD}$ \\
$\mathrm{B}$ & 1,30 & Sedang & 0,39 & Rendah & 0,54 & $\mathrm{AD}$ \\
$\mathrm{C}$ & 1,26 & Sedang & 0,36 & Rendah & 0,57 & $\mathrm{AD}$ \\
$\mathrm{D}$ & 1,47 & Sedang & 0,74 & Tinggi & 0,41 & TAD \\
\hline
\end{tabular}

(Deltuca) [coarctata] arcuata, Uca sp., dan Acetes sp. memiliki pola sebaran berbeda pada setiap stasiun yang ditemukan (mengelompok dan acak). Ha ini berbeda dengan penelitian Hartati et al. (2008) yaitu rata-rata krustasea di Ujung Pangkah Gresik memiliki pola sebaran 
mengelompok (clumped). Pola sebaran ditentukan oleh adanya sifat alami dari dalam individu itu sendiri, yaitu sifat genetika dan kesenangan (preferensi) dalam memilih habitat serta adanya interaksi dari beberapa faktor antara lain: sebaran makanan dalam ruang dan waktu, serta adanya kompetisi dalam pemanfaatan sumber daya habitat yang disebabkan adanya dampak keekstriman dari kondisi lingkungannya. Dalam hal ini penulis mengalami kendala dalam pengambilan sampel yang akurat untuk pola sebaran disebabkan kurangnya jumlah plot sampling mengingat karakter krustasea terutama kepiting yang bersifat motile. Wijaya dan Pratiwi (2011) menyebutkan bahwa persebaran krustasea tergantung dari kondisi lingkungan. Kondisi lingkungan yang sesuai akan sangat mendukung kehidupannya sehingga keberadaanya di setiap stasiun akan berbeda-beda tergantung dari kondisi lingkungan dimana krustasea berada. Krustasea secara ekologis merupakan sumber makanan penting bagi ikan dan predator lain, sebaliknya krustasea juga sering menjadi predator bagi makhluk kecil lainnya (Pratiwi dan Astuti, 2012). Larva krustasea yang merupakan komponen utama zooplankton sangat penting dalam rantai makanan biota laut lainnya.

\section{Kesamaan Komunitas Krustasea}

Nilai Indeks Kesamaan Komunitas pada lokasi penelitian menunjukkan kategori rendah dan tinggi. Dimana Indeks Kesamaan Komunitas berkategori tinggi mendominasi sebesar 76,19\% dan kategori rendah 13,33 \%. Rendahnya nilai kesamaan komunitas ini dikarenakan kecilnya nilai kelimpahan jenis krustasea yang berada pada Stasiun D, dibandingkan dengan stasiun lainnya. Hal ini juga dipengaruhi oleh kondisi mangrove yang masih baru dan sedikitnya kandungan bahan organik pada lokasi tersebut.

Tabel 4. Nilai Indeks Kesamaan Komunitas krustasea antar stasiun di kawasan vegetasi mangrove Tugurejo, Semarang

\begin{tabular}{ccccc}
\hline Stasiun & $\mathrm{A}$ & $\mathrm{B}$ & $\mathrm{C}$ & $\mathrm{D}$ \\
\hline $\mathrm{A}$ & $\mathrm{X}$ & $66,67 \%^{*}$ & $64,29 \%^{*}$ & $19,05 \%^{* *}$ \\
$\mathrm{~B}$ & & $\mathrm{X}$ & $76,19 \%^{*}$ & $14,29 \%^{* *}$ \\
$\mathrm{C}$ & & & $\mathrm{X}$ & $13,33 \% \%^{* *}$ \\
$\mathrm{D}$ & & & & $\mathrm{X}$ \\
\hline
\end{tabular}

Keterangan : * = Kategori Tinggi, $* *=$ Kategori Rendah

\section{Perbandingan Jenis Kelamin}

Pengamatan jenis kelamin dan betina yang bertelur dilakukan terhadap krustasea dari infra ordo Brachyura dikarenakan infra ordo tersebut mudah untuk mengetahui jenis kelaminnya. Secara umun jumlah individu pada krustasea jantan lebih banyak ditemukan dibandingkan dengan krustasea betina, dengan prosentase jantan $61 \%$ dan untuk betina $39 \%$. Infra Ordo Brachyura sendiri paling banyak ditemukan pada Stasiun B, untuk Stasiun D infra ordo tersebut hanya 2 jenis yang ditemukan. Untuk individu betina yang bertelur hanya 23,07 $\%$ dari jumlah Infra Ordo Brachyura betina yang ditemukan pada semua lokasi penelitian.

Hasil pengamatan terhadap Infra Ordo Brachyura betina yang bertelur, menunjukkan jumlah Brachyura yang bertelur paling banyak di Stasiun B. Hal ini dikarenakan kondisi vegetasi yang lebat dan mengandung banyak bahan organik dibanding stasiun lainnya. Nybakken (1992) menyatakan ketersediaan makanan yang cukup dapat meningkatkan kemampuan reproduksi biota. Ketersediaan bahan organik yang tinggi diduga akan meningkatkan asupan nutrien bagi krustasea tersebut dan pada akhirnya meningkatkan kemampuan reproduksinya.

Tabel 5. Jumlah Individu (ind.) dan Prosentase (\%) Infra Ordo Brachyura Jantan dan Betina di kawasan vegetasi mangrove Tugurejo, Semarang.

\begin{tabular}{cccc}
\hline Stasiun & Jantan & Betina & Bertelur \\
\hline A & 17 & 11 & 3 \\
B & 27 & 24 & 5 \\
C & 17 & 2 & 1 \\
D & 0 & 2 & 0 \\
\hline Jumlah & 61 & 39 & 9 \\
\hline Prosentase & $61 \%$ & $39 \%$ & $23,07 \%$ \\
\hline
\end{tabular}

\section{Parameter Lingkungan}

Parameter lingkungan pada setiap stasiun penelitian secara umum menunjukkan bahwa sebagian data cukup variasi dan sebagian kurang bervariasi antar lokasi. Nilai parameter lingkungan yang diukur meliputi suhu $\left({ }^{\circ} \mathrm{C}\right)$ derajat keasaman $(\mathrm{pH})$, dan salinitas $(\%$ oo $)$ yang diukur dari air pori sedimen.

Hasil pengukuran parameter lingkungan pada lokasi penelitian memiliki suhu rata-rata bekisar antara $29,7-30,3{ }^{\circ} \mathrm{C}$, suhu rata-rata terendah berada pada Stasiun A. Diduga bedanya suhu rata-rata tiap stasiunnya dipengaruhi oleh tutupan vegetasi mangrove disekitarnya, jenis sedimen, dan waktu sampling penelitian. Faktor lingkungan yang paling berpengaruh pada penelitian ini adalah bahan organik, dimana kondisi mangrove mempengaruhi banyak 
Tabel 6. Nilai Parameter Lingkungan (Air pori) di kawasan vegetasi mangrove Tugurejo, Semarang

\begin{tabular}{cccccc}
\hline Stasiun & Suhu $\left({ }^{\circ} \mathrm{C}\right)$ & Salinitas $(\%$ oo $)$ & $\mathrm{pH}$ & Bahan Organik (\%) & Sedimen \\
\hline A1 & 28,5 & 10 & 8 & 14,15 / Sedang & Pasir Lanauan \\
A2 & 29 & 19 & 8 & 14,43 / Sedang & Pasir Lanauan \\
A3 & 31,7 & 18 & 8 & $14,21 /$ Sedang & Lanau Pasiran \\
\hline Rata-rata & 29,7 & 15,7 & 8 & $14,26 /$ Sedang & \\
\hline B1 & 30 & 21 & 8 & 16,14 / Sedang & Pasir Lanauan \\
B2 & 30 & 24 & 9 & 19,43 / Tinggi & Pasir Lanauan \\
B3 & 31 & 23 & 8 & $17,41 /$ Tinggi & Lanau Pasiran \\
\hline Rata-rata & 30,3 & 22,7 & 8,3 & $17,66 /$ Tinggi & \\
\hline C1 & 31 & 28 & 8 & 4,08 / Rendah & Pasir Lanauan \\
C2 & 30 & 28,5 & 7 & 5,12 / Rendah & Pasir \\
C3 & 27 & 27,5 & 8 & 5,98 / Rendah & Pasir \\
\hline Rata-rata & 29,3 & 28 & 7,7 & $5,06 /$ Rendah & \\
\hline D1 & 30 & 28 & 7 & $4,79 /$ Rendah & Pasir \\
D2 & 29 & 28 & 8 & 4,99 / Rendah & Pasir \\
D3 & 31 & 28,5 & 8 & $4,89 /$ Rendah & Pasir \\
\hline Rata-rata & 30 & 28,2 & 7,7 & 4.89 / Rendah & \\
\hline
\end{tabular}

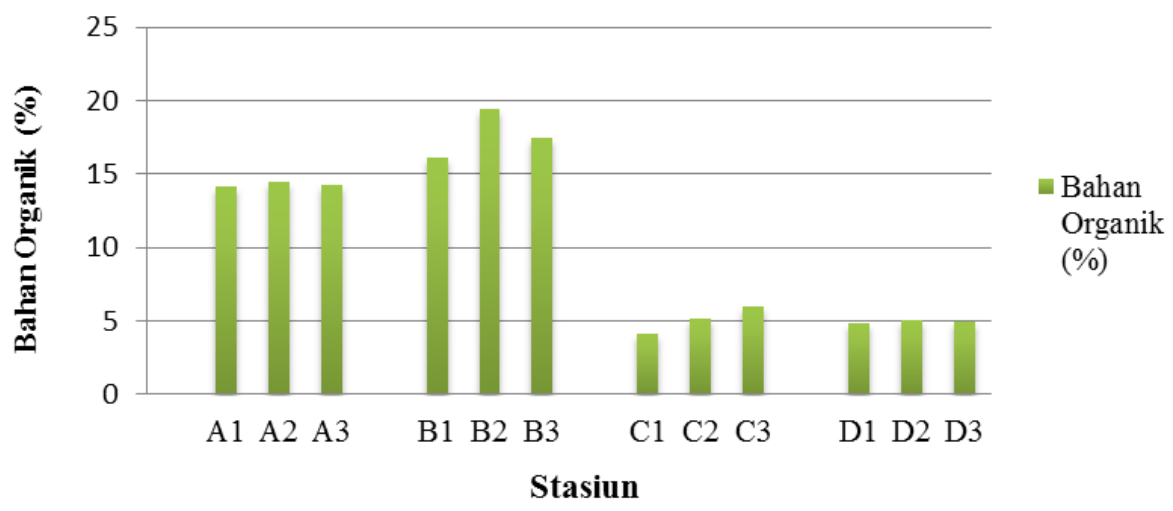

Gambar 1. Kandungan Bahan Organik sedimen di kawasan vegetasi mangrove Tugurejo, Semarang

\section{KESIMPULAN}

Krustasea yang ditemukan 22 jenis, terdiri dari 11 famili dan dua infra ordo. Dari Infra Ordo Brachyura ditemukan 5 famili yang terdiri dari 14 jenis, Untuk infra ordo Macrura ditemukan 4 famili yang terdiri dari 4 jenis, kemudian Isopoda ditemukan tiga jenis, dan untuk Copepoda ditemukan satu jenis. Kelimpahan krustasea tertinggi terdapat pada Stasiun B (1136 ind. $\left./ 25 \mathrm{~m}^{2}\right)$ dengan kerapatan mangrove terbesar (2089 ind./ha) dan kelimpahan terendah pada Stasiun D (83 ind. $/ 25 \mathrm{~m}^{2}$ ) dengan kondisi mangrove sapling dan secdling. Nilai indeks keanekaragaman (H') semua stasiun berkategori sedang, nilai indeks keseragaman (e) Stasiun A dan D berkategori tinggi dan Stasiun B dan C rendah. Indeks dominasi Stasiun A dan D berkategori TAD (Tidak Ada Dominansi) dan Stasiun B dan C AD (Ada Dominansi). Pola sebaran krustasea pada lokasi penelitian sebagian besar termasuk dalam kategori mengelompok/clumped. Nilai indeks kesamaan komunitas termasuk dalam kategori tinggi (Stasiun A-B, A-C, B-C) dan rendah (Stasiun A-D, B-D, C-D). Jumlah Infra Ordo Brachyura menurut jenis kelaminnya menunjukkan jantan lebih banyak dari betina, dan jumlah betina yang bertelur $9,18 \%$ dari jumlah betina yang ditemukan pada lokasi penelitian.

\section{UCAPAN TERIMAKASIH}

Penulis menyampaikan terimakasih kepada Sdr. Miftahul Ulum dan Mahfud atas bantuannya selama survey lapangan.

\section{DAFTAR PUSTAKA}

Burukovskii, R.N. 1982. Key to Shrimps and Lobsters. Oxonian Press PVT LTD. New Delhi, India. 174. 
Brower JE., Zar, J.H. \& Ende, C.N. 1990. Field and Laboratory Methods for General Ecology. 3rd

Ed. Wm C. Brown Publishers. United States of Amerika.

Carpenter, K.E. \& Niem, V.H. 1998. FAO Species Identification Guide for Fishery Purposes: The Living Marine Resources of The Western Central Pacific. Volume 2: Cephalopods, Crustaceans, Holothurians and Sharks. Food and Agriculture Organization of The United Nations. Rome. 1367 p.

Hartati, R., Widianingsih \& Prasetyo, Y. 2008. Komposisi dan Kelimpahan Krustasea di Kawasan Mangrove Muara Sungai Bengawan Solo, Ujung Pangkah - Gresik. Ilmu Kelautan: Indonesian Journal of Marine Science. 13(1): 49 -56

Hall, D.N.F. 1962. Observation on The Taxonomy and Biology of Some IndoWest Pasific Penaeidae. (Krustasea-Decapoda). Field Publication Colonial of London, 17:176-229

Hogarth, P.J. 2007. The Biology of Mangrove. Oxford University Press. Inc. New York. 77115.

Holthuis, L.B. 1955. The Recent Genera of the Caridean and Stenopodideae Shrimps (Class krustasea, Order Decapoda Supersection Natantia) with Keys for Their Determination. Rijksmuseum van Natuurlijke Historie, Leiden, Netherlands. 157.

Krebs, C.J. 1989. Ecological Methodology. Harper Collins Publishers. New York: 293 368.

Lardicci, C., Rossi, F. \& Castelli, A. 1997. Analysis of Makrozoobenthic Community Structure after Severe Dystrophic Crises in a Mediterranean Coastal Lagoon. Mar. Pol. Bull, 34(7): 536- 547

Ng Peter, K.L., Keng, W.L. \& Lim, K.K.P. 2008. Private Lives an Expose of Singapore's Mangroves. The Raffles Museum of Biodiversity Research.Singapore. 249.
Nontji, A. 1987. Laut Nusantara. P.T. Djambatan. Jakarta. Hal 189-198.

Odum, E.P., 1971. Fundamental of Ecology. W.E Saunders, Philadelphia, 574.

Odum, E.P. \& Heald, E.J. 1975. Mangrove Forest and Aquatic Productivity. Introduction to Land - Water Interaction (Ecological Study Series), pp. 129-136. Springer-Verlag. Berlin.

Pratiwi, R. \& Astuti, O. 2012. Biodiversitas Krustasea (Decapoda, Brachyura, Macrura) dari Ekspedisi Perairan Kendari 2011. Ilmu Kelautan : Indonesian Journal Of Marine Science 17(1):8-14

Rahayu, D.L., \& Setyadi, G. 2009. Mangrove Estuary Crabs of The Mimika Region, Papua, Indonesia. PT Freeport Indonesia-LIPI. Papua. 154.

Saenger, P. 2002. Mangrove Ecology, Silviculture and Conservation. Kluwer Academic Publishers, London, $351 \mathrm{hlm}$.

Saenger, P. \& Hutchings, P. 1987. Ecology of Mangrove. Unversity of Queenland Press. London.

Sakai, T. 1976a. Crabs of Japan and The Adjacent Seas. Plates. Kodarian LTD. Japan. 773p.

Sakai, T. 1976b. Crabs of Japan and The Adjacent Seas Figures. Kodarian LTD. Japan. 251p

Sasekumar, A. 1974. Distribution of Macrofauna on Malaya Mangrove Shore. The Journal of Animal Ecology vo. 43: pp 51 - 69.

Snedaker, S.C., \& Snedaker, J.G., 1984. The Mangrove Ecosystem: Research Methods. UNESCO, Paris.

Suryabrata, S. 1992. Metodologi Penelitian. Rajawali Press. Jakarta $86 \mathrm{hlm}$.

Wijaya, N.I. \& Pratiwi, R. 2011. Distribusi Spasial Krustasea di Perairan Kepulauan Matasiri, Kalimantan Selatan. Ilmu Kelautan: Indonesian Journal Of Marine Science 16(3): $125-134$ 